\title{
Electoral Strategy In The Ancient Rome: Case Study Of Commentariolum Petitionis
}

Alicia Valmaña-Ochaíta. Ph.D., University of Castilla-La Mancha, Spain

\begin{abstract}
Rome presents, once more time, the reality of its time like a mirror in which we can see reflected many daily realities. One of them is the strategy in an electoral campaign. The text of Commentariolum petitionis is an excellent example of how the marketing, also the electoral marketing, is a reflection about what the market needs or how to create market, now and in the Ancient Rome.
\end{abstract}

Keywords: Commentariolum Petitionis; Cicero; Propaganda; Electoral Marketing

\section{INTRODUCTION}

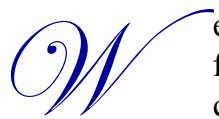

e live in a world in which Publicity and Communication are part of our lives; they have a common field that belongs to their own signification: both of them pretend to make public something and contain information that passes from a person to another; connected with that, there is another sense, perhaps more social or sociologic, which is referred to the mechanisms that one or more people use to make that the information reaches to the others.

In this sense, the behavior of the political establishment, focused to the necessity of publicity of the candidate, is an important field of study in these subjects in any developed system, and, in spite of Ancient Rome had not got a Communication, Publicity or Electoral marketing Sciences, the roman candidate, from the Republic time, had similar characteristics as the one of nowadays. In fact, since the Greeks, the rhetoric occupied this field "as the art of the social communication that aspired to persuade to the citizens by means of the language" (López Eire, 2003, 12).

This necessity of the politician to make public his politics can be seen when he is a candidate, and his pretension is to reach to the elector; when he is in power, and when the moment of the end is arriving, and he must communicate all the things he has done; this necessity to establish communication laces was already present in Rome, and was a fundamental base for its own political survival. But this behavior goes into the, so named, in a general sense, propaganda.

Propaganda is a phenomenon of communication that tries to propagate ideas or doctrines of a determinate group, with the aim of persuade to the others about the goodness of them to get followers or supporters (about the origins and develop of the propaganda, Méndiz, 2008, 53). The ideas of subjectivism or persuasion caused that the word had a pejorative connotation, perhaps, also, by the instruments used to reach the cited purpose to obtain supporters.

We can find in Rome some skills associated to electoral campaigns, but the most amazing thing is that these campaigns were thought and written for a candidate. It is not only to persuade to the others, like Aristotle thought that men could practice the Politic using their oratory ability and, consequently, exercising "the main function of the rational language or lógos, that is, persuade the others" (López Eire, 2003, 25), but to analyze the mechanisms, tools and behaviors that a candidate must put in practice to get votes. 


\section{A HANDBOOK OF ELECTORAL CAMPAIGN: COMMENTARIOLUM PETITIONIS ${ }^{1}$}

Commentariolum petitionis is a brief text, written by Quintus Tullius, the smaller brother of the great Marcus Tullius Cicero, dated circa 64 b.C. The opusculum contains the reflections of Quintus about the electoral campaign of his brother, who was being postulating to accede to the consulate; actually, it was a number of advices that Quintus tells to Marcus with regard to the special method for the design and for the development of the electoral campaign.

Commentariolum has been historically considered from a general and timeless perspective, might be, as it happens when we analyse the classic texts; the considerations written by Quintus about the electoral campaign to the consulate, have been projected towards the electoral campaigns at the end of the Roman Republic and, with a certain timeless view, towards our days, either, as valid advices, or as techniques or situations that are still alive nowadays (widely, Fezzi, 2007, 14-16).

However, the absolutely specific character of the text is unquestionable (widely, Nardo, 1970, $57 \mathrm{ff}$ and Pina, 1990, 71); it is a brief treatise written ad hoc, for a concrete campaign: the basic content of the Commentariolum is the electoral campaign of Marcus starting in 64 b.C., or going imminently to start.

This impression is reflected along the whole work and it is especially emphasized in the last paragraph of the text when Quintus says that he has not written these ideas to be utilized for all that aspire to a magistracy, but, particularly, for his brother and for this concrete candidature-Quae tametsi scripta ita sunt ut non ad omnis qui honores petant sed ad te proprie et ad hanc petitionem tuam valeant (XIV, 58)-. The all references to the opponents and to the condition of homo novus of Cicero -circumstance which was present in this campaign for the access to the consulate for the first time, and which worried to the brothers, especially- go in this direction. The conclusion is that if the candidate was other one, or the same Marcus was for another magistracy, or for the second consulate, the advices would be different, or, at least, some of them.

That is not a handicap to draw general ideas, valid to any electoral campaign, in the old Rome or nowadays as I just have said, among other reasons because the text compiles, together the particulars aspects of the electoral campaign of 64 b.C., other general matters. So, all the chapters from the V voice ideas or advices absolutely available by any candidate, although they are always mixed with the special form to apply them, attending to the qualities and circumstances of Marcus. For example, chapters VIII and IX are dedicated to how to win the support of the centuries (comitia centuriata), of the senators and the equites, and, in general, of the all kind of citizens: from the city and from de villages, especially young people that, with their insistence and determination when they ask for the votes, or visit people, or make propaganda, and go with the candidate, become one of the most effective instruments of electoral propaganda -Nam studia adulescentulorum in suffragando, in obeundo, in nuntiando, in adsectando mirifice et magna et honesta sunt (VIII, 33)-. These advices are perfectly applicable to any campaign, any time, but they have been thought for this concrete campaign, for instance, when Quintus emphasizes the different situation and attitude of Marcus in front of the inhabitants more distant from Rome; Marcus has met them yet and so, it will be more easy to become friendly with them that his opponents which do not meet these people -Hos ceteri et maxime tui competitores ne norunt quidem, tu et nosti et facile cognosces, sine quo amicitia esse non potest (VIII, $31)$.

So, either the concrete references, or the general ones, live together in the text; really, the second ones are based on the first ones. But, in the perspective that I propose, it is very significant how, in the It. century before Christ, it could be designed an electoral campaign with the elements that we can detect in the present ones, except, of course, in the using of the mass media (Fezzi, 2007, 22ff and Morstein-Marx, 1998) -however, other possibilities of communication and propaganda with the electors were used; we only have to remember the graffiti in the walls, supporting or being against the different candidates, especially those in Pompeii, (Weeber, 2007; Bravo, 2010, 14ff). And, this is because the fundamental aim is the same any time: to persuade the electors and to get supporters, and finally, votes.

\footnotetext{
${ }^{1}$ I have used the Latin text established in the edition of Watt, "M. Tulli Ciceronis. Epistulae" (vol. III), Oxford University Press, 1958 
The strategy of Quintus to obtain votes is designed along his letter with a discourse perfectly constructed, with divisions and subdivisions of the different issues to study (widely Nardo, 1970. 94); from the point of view of the content, we can divide it in two large categories (besides the philological studies that have insisted specially in the question of the authenticity, the study of the Commentariolium has been focused, normally, to the political situation in Rome at the end of the Republic, with a special reference to the use of the clientela or the political friendships (Morstein-Marx, 1998, 259ff):

- $\quad$ The issues that the candidate must internalize.

- $\quad$ The issues that the candidate must externalize.

In other words, the analysis of strengths and weaknesses, opportunities and threats (known nowadays as SWOT), preliminary to the action over the electorate, in such a way that we find something classic in the current electoral marketing. In Commentariolum petitionis, the two questions -the things that the candidate must internalize and the things that the candidate must externalize- are considered in a united way because, indeed, the first one serves to the interests of the second one; so, paying attention to a classical division, when the candidate does this inner view, he must answer three questions: who I am?, what do I try to?, where I am?.

The answer of Quintus for his brother is well known: "Novus sum, consulatum peto, Roma est" (I, 2). Along to these three inner reflections about the condition of the candidate are structured the actions in front of the electorate which will basically go in two directions:

- $\quad$ The search of the support of the friends $(\mathrm{V}-\mathrm{X})$

- $\quad$ The search of the popular favour. (XI-XIII)

[ "Et petitio magistratuum divisa est in duarum rationum diligentiam, quarum altera in amicorum studiis, altera in populari voluntate ponenda est” $(\mathrm{V}, 16)]$.

\section{§ AMICORUM STUDIUM. THE DETERMINATION OF THE FRIENDS}

As it has been frequently said (Fatás, 1990; Hellegouarc'h, 1972; Malavé Osuna, 2004), the word amicitia in Commentariolum has a wider sense than normally has -Sed hoc nomen amicorum in petitiote latius patet quam in cetera vita $(\mathrm{V}, 16)$ - and it might be understood as "political support"; so, one of the more important targets in a electoral campaign is to obtain the political favour of many people. But, it is not a simple search of supports in general: that issue will be discussed in the chapter XI -our next § POPULAREM FAMAM-. Now, they must try to search the friendship of certain sectors, groups of persons that can be determinant to influence with their vote in the vote of their centuries; the target is, as I have said in Introduction, to persuade to the receptors of the message, with the aim of use them for gain more supporters to the candidate.

So, it must be distinguished the amicitia as a traditional roman virtue from this political amicitia (Pina, 1990, 86ff; Nardo, 1970, 95ff; Hellegouarc'h, 1972, 160ff; Morstein-Marx, 1998, 270ff; Lucrezzi, 1998, 426ff), that we can almost describe as if it were referred to the present moment, searched and reached for a concrete election and that, in consequence, it could change in other circumstances -although it can became in a strong and durable friendship, non brevem et suffragatoriam sed firmam et perpetuam amicitiam (VII, 26), because the special personality of Marcus-.

The sectors in which Marcus must be close up, getting or reaffirming, if it already existed, their friendship, expresses, without doubts, the use of the friendship as electoral mechanism (regarding this, Pani, 2007, 305ff). Quintus, in an absolutely natural way, has designed the strategy in perfect way starting from this political tool.

1.- (AMICORUM). In the first place, Quintus analyses, objectively, which groups the campaign is focused, and what is what he tries to obtain from each of them. From a general perspective, the candidate must procure the friendship of anybody that expresses his liking to him, that treats him with consideration or frequently visits his home -quisquis est enim qui ostendat aliquid in te voluntatis, qui colat, qui domum ventitet, is in amicorum numero est habendus $(\mathrm{V}, 16)$ - 
It is necessary to maintain and reinforce friends, and, in general, to the closer people -tribules, vicini, clientes, incluso liberti y servi, $(\mathrm{V}, 17)$ - whose opinion about the candidate will be got into consideration by the public opinion -nam fere omnis sermo ad forensem famam a domesticis emanat auctoribus, (V, 17)-.

It is necessary "to create" friendship between the famous men by their birth or their highly-placed, between the magistrates, and between men with influence into the centuries. The first ones are needed in order to their appearances -dignitas-, although they do not make a great effort commending to the candidate; the second ones are needed to avoid any problem with Law, and the third ones - generally ambitious men-, in order to determine, with their vote, the vote of the centuria -ad speciem, homines inlustres honore ac nomine (qui etiam si suffragandi studia non navant, tamen adferunt petitori aliquid dignitatis); ad ius obtinendum, magistratus (ex quibus maxime consules, deinde tribuni pl.); ad conficiendas centurias homines excellenti gratia (V, 18)- (regarding the "ambitious men", vote-brokers, according his own expression, which do not form part of the nobility, (Morstein-Marx, 1998, 276ff).

This last group of persons deserves a special dedication because they are who can actually incline the result of the election towards the candidate -Hos tu homines, quibuscumque poteris rationibus, ut ex animo atque ex [illa] summa voluntate tui studiosi sint elaborato $(\mathrm{V}, 18)$-. Some of them form part of a sodalitas, a kind of fraternity, or association that, born to share some kind of religious ceremonies, as time passed through, it was dedicated, more specifically, to reinforce fidelities or political supports, as it could be deduced from the text; it would appear, then, that the sodalitates were the first pressure, or influence, groups in a elections. In consequence, the priority to gain the support of the most influential persons in the sodalitates is perfectly understood as one of the basic elements in any electoral campaign -PINA (1990, 88ff) asserts that in the moment in which Quintus wrote his Commentariolum, the sodalitas does not have the pejorative sense that the concept of sodalicium lately assumed. About the distinction between sodalitas and sodalicium, vide Hellegouarc'h, 1972, 109-110-.

In any case, it must be found the amicitia, the supports in the whole Rome, in the whole Italy, without underestimate any corporation, village, district or region, tribe by tribe, to the city's inhabitants, or to the countrymen -Deinde habeto rationem urbis totius, conlegiorum omnium, pagorum, vicinitatum[...] totam Italiam [...] omni regione [...] Homines municipales ac rusticam, (VIII, 30 y 31)-.

An internal slogan appears in the text: "Nothing is more stupid than thinking that somebody who you do not meet will be your follower" -mihi quidem nihil stultius videtur quam existimare esse eum studiosum tui quem non noris (VII, 28)-. It is necessary to look for, then, all the votes, and is necessary to obtain them, one by one, and we can only gain them, arriving to every far-off corner.

2.- (STUDIUM) In the second place, Quintus analyses subjectively what moves to the different groups to deliver their support to a candidate, in order to better use each one of them -Sed quoniam tribus rebus homines maxime ad benevolentiam atque haec suffrragandi studia ducuntur, beneficio, spe, adiunctione animi ac voluntate, animadvertendum est quem ad modum cuique horum generi sit inserviendum" (VI, 21)-. There are three fundamental reasons:

- The favours that the candidate has done in the past. To respond to the received favour-beneficium- is a duty of every Roman and if they do not repay to the candidate with their support, nobody respected them (they will not return to be considered by anybody) -si hoc tuo tempore tibi non satis fecerint, se probatos nemini umquam fore (VI, 21, and also in V, 19 y 20, qua re hoc tibi faciendum est, hoc tempore ut ab his quod debent exigas saepe commonendo, rogando, confirmando, curando ut intellegant nullum se umquam aliud tempus habituros renferendae gratiae. . On the other hand, it will be a good idea to hint that the debtor's condition could be reversed from this moment, becoming the candidate, the elector's debtor -etiam in hanc opinionem adducendi ut, qui adhuc nobis obligati fuerint, iis vicissim nos obligari posse videamur (VI, 21 in fine)-.

- The expectations that his candidature arises in certain people: it is necessary to persuade them that the candidate is very conscious of what each one does for him; that, the favours received are appreciated, and that they will be considered in the future -his hominum generibus sic inserviendum est ut ipsi intelligant te videre quid a quoque exspectes, sentire quid accipias, meminisse quid acceperis (VI, 24 y 22)-. Equally, the candidate must treat to the "volunteers" that, suddenly, decide to support to him; however, the candidate must be careful with these ones, 
in such a way they are indeed valued positively by their tribules, and not persons with a bad reputation who could provoke the effect in opposition to the expected one -Sunt autem alii qui aut nihil possunt aut etiam odio sunt tribulibus suis nec habent tantum animi ac facultatis ut enitantur ex tempore; hos ut internoscas videto, ne spe in aliquo maiore posita praesidi parum comparetur (VI, 24)-.

The unconditional supporters cannot be forgotten, on the contrary, we must really demonstrate to them that their friendship will be lasting and close and we will be always grateful with them -adducenda amicitia in spem familiaritatis et consuetudinis confirmari oportebit (VI, 23)-.

In all these cases, it is established a certain reciprocity (Hellegouarc' $\mathrm{h}, 1972,154)$ between the candidate and those people whom he comes close because a new amicitia, or a reinforced amicitia; reciprocity in which the three elements -officium, beneficium, meritum-, are complemented one to each other to become in the fundamental reason to support the candidate.

But, if all of this is referred to a more or less small circle of people whom the candidate can be approached, this is, the circle of political friendships or the political support that the candidate tries to obtain, all of them are, as well, in the way that they are converted in a instrument to obtain the popular favour (Morstein-Marx, 1998, 272ff; regarding the retinue that follows to the candidate and the acts that they do in his favor, see the long section IX, and, widely, Hellegouarc'h, 1972, 160ff and Morstein-Marx, 1998, 271-272). Now, already of course, the whole populus. -quibus multitudinem capere possis (XII, 49)-.

\section{§ POPULAREM FAMAM. POPULAR FAME.}

The second great question for any candidate is how to achieve the popular fame; if we analyze the advices of Quintus for his brother, it seems that the things have not changed so much, from the old times to nowadays: flatteries, exaggerations, simulations, visibility, constant and familiar treatment, and generosity - Ea desiderat nomenclationem, blanditiam, adsiduitatem, benignitatem, rumorem, speciem in re publica (XI, 41)-. And all of it into the perfect balance between what it is accepted, even what it is required in these questions, and what is political "corruption". In this sense, the text does not reflect any type of corruption, although some attitudes could be understood as abuses, at least; regarding this, the references to the "economic" generosity, especially those that appears in XI, 44 with regards to XIII, 52 and XIV, 57, show the practices to us of largitiones and how their deviance, more and more frequents, provoked the approval of the leges de ambitu - Calpurnia in year 67 b.C. and Tullia in the year 63 a.C.- (about the differences between largitiones and liberalitas and the contain of the functions of diuisores and sequester, PINA, 1990, 78ff).

The important thing is that what the candidate is doing, be highlighted, and what the candidate lacks, be hidden; the candidate must be always making electoral campaign, uninterruptedly; he must be able to adapt to the circumstances, accommodating to the thought of the voter, saying to him what he wants to hear; he must be fully generous, either in the economic aspects, or in the attention that the citizens required (XI, 42-44). All of this, turns the candidate in a popular man.

The importance of the public opinion is essential for the candidate. And the auspicious public opinion is reached by an addition of the all activities that the candidate must do in the electoral campaign. The resume of all of them that Quintus do in XIII, 50-51 is splendid; it is only to analyze an issue: the external form -Postremo tota petitio cura ut pompae plena sit, ut inlustris, ut splendida, ut popularis sit, ut habeat summam speciem ac dignitatem (XIII, 52), that is, that the whole campaign be full of pomp, be brilliant, magnificent, popular, and have a wonderful aspect and dignity.

If until this moment, the advices of Quintus in the Commentariolum petitionis are a reflection with regards to the object of the campaign, now all goes around the form, around the esthetic of the campaign. It goes from the advices about the behaviors, about what must be done, to the forms, to how must be done. And between them, a last advice: it is profitable that the campaign go to the disrepute of the adversary -ut etiam, si qua possit <ratio>ne, competitoribus tuis exsistat aut sceleris aut libidinis aut largitionis accommodata ad eorum mores infamia (XIII, $52)$. 
Actually, Quintus had dedicated the first pages to the criticism of the opponents of Marcus and he returns towards this in the last chapter, XIV, when, speaking about of the third great idea of the campaign, "Roma est", the allusions to the corruption in the electoral campaigns are repeated, making them the only issue of the discourse -Et quoniam in hoc vel maxime est vitiosa civitas, quod largitione interposita virtutis ac dignitatis oblivisci solet [...] (XIV, 55); Video nulla esse comitia tam inquinata largitiones quibus non gratis aliquae centuriae renuntient suos magno opere necessarios (XIV, 56); ...sequestribus metum inicimus, divisores ratione aliqua coercemus, perfici potest ut largitio nulla fiat aut nihil valeat (XIV, 57)-. However, the important thing, again, is the advice about what the candidate must do in this situation and this is just to use his strengths up the maximum against to his adversary. In the case of Marcus Tullius Cicero, his greatest strength is the oratory (about this question in general and with specific to the Commentariolum, Panchón Cabañeros, 1998, 286f), and the scare of his opponents with regards to Marcus is that he used his best arm against them, initiating a legal process that finish in a sentence of their political enemies -id est ut intellegas eum esse te qui iudici ac periculi metum maximum competitoribus adferre possis(XIV, 55); in fact, it is treated that the opposites not do fraudulent operations because the scare caused by the thought that Marcus can accuse them -Atque haec ita te nolo illis proponere ut videare accusationem iam meditari, sed ut hoc terrore facilius hoc ipsum quod agis consequaere- (XIV, 56). In other words, the aim of the campaign is not state publicly the corruption of the adversaries, but they feel the threat of the vigilance $-F a c$ ut se abs te custodiri atque observari sciant- (XIV, 55) (regarding the electoral corruption, widely, Chenoll, 1984; Resina, 2011 and Castán, 2012).

This advice about the necessity of a vigilance of the opponents has invited many academics to think that the aim of the opusculum of Quintus was to give a more o less limited diffusion between friends or other people, which is considered suitable to make arrive it, in order to gain their political support. The agent of this diffusion would have been Aticus (Nardo, 1970, 56ff and 137); this is assumed, normally (Pina, 1990, 28; Fatás, 1990, 30; Duplá, 1988, 113ff. Vide, widely, other arguments, like the worry of Quintus because the result of his text were not perfect, in all the aspects -volo enim hoc commentariolum petitionis haberi omni ratione perfectum (XIV, 58)-, so he ask for his brother to make the necessary corrections or suppressions. -tamen tu, si quid erit praeteritum, velim hoc mihi dicas (XIV, 58) and the arguments in opposite, in Nardo, 1970, 56ff).

In consequence, we are in front of the "bedside book" of Marcus Tullius Cicero in those electios in 63 b.C., but we are, in a certain mesure, as I have said at the beginning, in front of the "bedside book" of any candidate. So, perhaps, it must no be accepted the doubts about the authorship of the text based in reason of "common sense" (Duplá, 1990, 23, although the author defends the autenticity of the text), in which is relieved the lesser ackonwnledge of Quintus than Marcus. The discussion about the autenticity of the authorship is not closed, although after the debate that was produced in former times, and, basically, because the study of Nardo, the balance seems to incline towards the autenticity (widely, Lucrezzi, 1998, 415ff; a good resume of the all opinions in Duplá, 1990, 23ff; Morstein-Marx, 1998, 260-261; Núñez González, 1999, 233-254).

In my opinion, being exact the premise regarding the smaller experience practice, it is also true that Quintus is working for his brother like a real electoral campaign manager of any leader of a current political party (independently that at current democracies, with their regimen of political parties, are not comparable with the republican system in Rome, (Fezzi, 2007, 15 and 24); nevertheless, see also, (Torrent Ruiz, 2012).

As Quintus points to in his first words, when express the reason and justification of his writing, his aim is, only, to take charge of outline an strategy, of think and methodically write - ratione et distributione sub uno aspectu (I, 1)- those ideas that, the same Quintus recognize it, his brother knows much better -non ut aliquid ex his novi addisceres- but that, sometimes, they appear in the daily life dispersed and diffused -sed ut ea quae in re dispersa atque infinita viderentur esse- and what Marcus did not think about because he was too much busy in other questions -Haec sunt quae putavi non melius scire me quam te sed facilius his tuis occupationibus conligere unum in locum posse (XIV, 58)-. As I have said before, we are in front of one of the most clear, and old, worked development of electoral strategy and the tactics that must be used; so I think that, independently that the text had a diffusion more or less limited, and, in this sense, it had a certain purpose of electoral propaganda, the aspects of electoral design are more relevant in the text (in the way of the propaganda Flores Santamaría, 1998, 79). 
For this reason, Quintus is expressed himself with a hard sincerity when he refers to the voters, in a way of rules:

- $\quad$ Those things that you must do, show yourself willing to do them with pleasure and dedication -ut quod facturus sis id significes te studiose ac libenter esse facturum (XI, 45)-

- $\quad$ If you are not able to do something, you might kindly refuse to do it, or do not refuse; the first is proper of a good man, but the second is proper of a good candidate-quod facere non possis, ut id aut iucunde <neges aut etiam non> neges, quorum alterum est tamen boni viri, alterum boni petitoris (XI, 45)-.

- $\quad$ And, regarding with the former: promises are better than negatives, because the first ones are in the air, have not a determinate deadline and affect to a limited group of people; in the opposite, negatives win for, without doubt and immediately, many enmities $-I d$, si promittas, et incertum est et in dime et in paucioribus; sin autem [id] neges, et certe abalienses et statim et pluris (XII, 48)-.

And last, but not least, on the contrary, the most overwhelming sentence: "All of them are the same: they prefer a lie prior a negative [...]"-omnesque hoc animo sunt ut sibi te mentiri malint quam negare [...] (XII, 46)-.

\section{CONCLUSION}

The idea of "know yourself" that appears at the beginning and the end of the text (I and XIV) and that links with the condition of homo novus of Marcus - disadvantage ab initio- is completed with the radiography of the opponents in the chapters II and III in this SWOT I have mentioned. Either the concrete diatribe against the opponents, or the exposition of virtues of Marcus could have a propagandistic aim from the first moment or it could be used with this aim, a posteriori, through the publication of the written, but this is a value judgement and it is not an obstacle to consider it as an argumentative handbook for the internal consumption of the candidate.

\section{AUTHOR INFORMATION}

Alicia Valmaña-Ochaíta, Degree in Law by University of Alcalá (Spain) and Ph.D. in Law by University of Castilla-La Mancha (Spain). Associate Professor at Roman Law (Public Law and Legal Science Department). Faculty of Legal and Social Sciences of Toledo. University of Castilla-La Mancha (Spain). Research Interest: Democracy. Democratic reforms in voting district in Rome. Contracts in Roman Law. Ownership in Roman law. Legal condition of women in the old world. Language and Law. E-mail: Alicia.Valmana@uclm.es

\section{REFERENCES}

1. Bravo Bosch, M. J. (2010). La eficacia de la propaganda en los procesos electorales de la Roma tardorrepublicana. Revista General de Derecho Romano http://www.iustel.com/v2/revistas/detalle_revista.asp?id=11, rescue, 2012/01/27, 1-21.

2. Castán Pérez-Gomez, S. (2012, at press). Corrupción electoral en la República Romana: Intereses del populus y la nobilitas en la lucha política. Anuario de la Facultad de Derecho de la Universidad de La Coruña (I want to thank the author for giving me the opportunity to read the original work).

3. Chenoll Alfaro, R. R. (1984). Soborno y elecciones en la República Romana. Málaga: Universidad de Málaga.

4. Duplá, A. (1990). La polémica sobre la autenticidad del Commentariolum petitionis. En A. Duplá, G. Fatás, \& F. Pina, El manual del candidato de Quinto Cicerón (El commentariolum petitionis). Erandio: Servicio Editorial de la Universidad del Pais Vasco, 23-29.

5. Duplá, A. (1988). Novus sum, consulatum peto, Roma est: el Comentariolim petitionis de Quinto Cicerón. Studia historica. Historia antigua (Ejemplar dedicado a: Homenaje a Marcelo Vigil , II (6), 107-116.

6. Duplá, A., Fatás, G., \& Pina, F. (1990). El manual del candidato de Quinto Cicerón. El commentariolum petitionis. Erandio: Servicio de Publicaciones de la Universidad del Pais Vasco.

7. Fatás, G. (1990). El Commentariolum petitionis. En A. Duplá, G. Fatás, \& F. Pina, El manual del candidato de Quinto Cicerón. El commentariolum petitionis. Erandio (Vizcaya): Servicio Editorial de la Universidad del Paid Vasco, 1-156. 
8. Fezzi, L. (2007). Il Commentariolum petitionis: sguardi dalle democrazie contemporanee. Historia: zeitschrift für alte geschichte : revue d'histoire ancienne 56 (1), 15-26.

9. Flores Santamaría, P. (1998). Un ejemplo de literatura propagandística: el Commentariolum petitionis de Q. Cicerón. En Actas IX Congreso Español de Estudios Clásicos (Vol. 5). Madrid, 77-81.

10. Hellegouarc' h, J. (1972). Le vocabulaire latin des relations et des partis politiques sous la République. París: Les Belles Lettres.

11. López Eire, A. (2003). La retórica en la publicidad (2ª ed.). Madrid: Arco Libros.

12. Lucrezzi, F. (1998). Commentariolum petitionis. Studia et Documenta Historiae et Iuris (LXIV), 413-439.

13. Malavé Osuna, B. (2004). Corrupción política y amistad en la Roma de Cicerón. En A. Calzada González, \& F. Camacho de los Ríos, Derecho Penal: de Roma al Derecho actual. Madrid: Edisofer, 351-365.

14. Méndiz Noguero, A. (2008). Diferencias conceptuales entre publicidad y propaganda: una aproximación etimológica. Questiones Publicitarias, vol. I, n $12,42-61$.

15. Morstein-Marx, R. (1998). Publicity, popularity and patronage in the Commentariolum Petitionis. Classical Antiquity , 17 (2), 289-420.

16. Nardo, D. (1970). Il "Commentariolum petitionis". La propaganda elettorale nella "ars di Quinto Cicerone". Padua: Liviana Editrice in Padova.

17. Núñez González, J. M. (1999). En torno al estilo del Commentariolum petitionis. En Corona spicea : in memoriam Cristóbal Rodríguez Alonso. Oviedo: Servicio de Publicaciones de la Universidad de Oviedo, 233-254.

18. Panchón Cabañeros, F. (1998). La oratoria y el candidato en tiempos de César. En Labiano, L. Eire, \& Seoane, Retórica, Política e Ideología (desde la antigúedad hasta nuestros días. retórica clásica y edad media) (Vol. I). Salamanca: Logo, 285-291.

19. Pani, M. (2007). Il modelo dell’obbligazione sociale nel Commentariolum Petitionis. En E. Lo Cascio, \& G. M. Merola, Forme di aaggregazione nel mondo romano. 303-312. Bari: Edipuglia.

20. Pina, F. (1990). La campaña electoral en Roma. En A. Duplá, G. Fatás, \& F. Pina, El manual del candidato de Quinto Cicerón (El commentariolum petitionis). Erandio: Servicio de Publicaciones de la Universidad del Pais Vasco, 1-156.

21. Resina Sola, P. (2011). La corrupción electoral en la comedia plautina. Revista General de Derecho Romano http://www.iustel.com/v2/revistas/detalle_revista.asp?id=11, rescue 2012/01/27, (16), 1-24.

22. Suárez Piñeiro, A. M. (2003). En campaña electoral por la Roma de Cicerón (La política romana a finales de la República). Verín-Santiago: Lóstrego.

23. Torrent Ruiz, A. (2012). Los partidos políticos en la República tardía. De los Gracos a César (133-44 a.C.). RIDROM [online] (8), http://www.ridrom.uclm.es, rescue 2012/05/23, 19-78.

24. Weeber, K.-W. (2007). Le Campagne Elettorali nell'antica Roma. Sant'Oreste RM: Apeiron. 